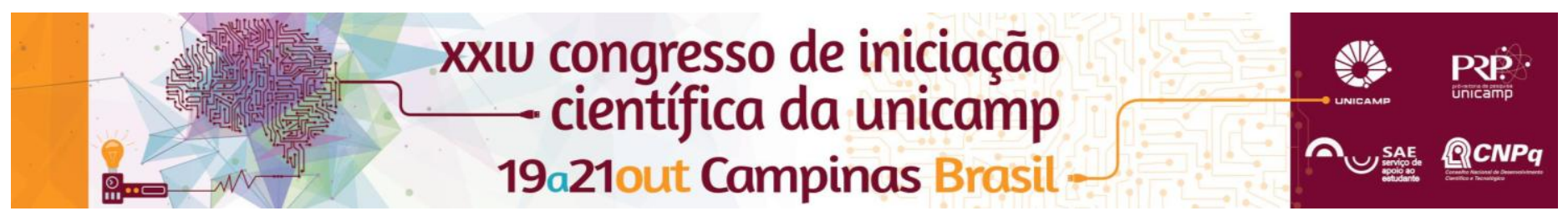

\title{
Estudo da expressão dos genes de globinas em células HEL mediante o silenciamento do gene PIP4KIla
}

\author{
Thais T. Jorge*, Daniela M. Ribeiro, Ana P. D. Costa, Susan E. D. C. Jorge, Maria F. Sonati
}

\begin{abstract}
Resumo
Diversos estudos têm demonstrado a possível relação existente entre a expressão gênica das globinas e as fosfatidilinositol-fosfato-quinases (PIPKs), dentre as quais a PIPK da família 4 do tipo II, pertencente ao subtipo a (PIP4KIIa) se destaca por apresentar os resultados mais significativos e reprodutivos em cultura de células de pacientes com doença de hemoglobina $\mathrm{H}$ e de células eritroleucêmicas imortalizadas. A fim de elucidar a interação entre tais proteínas, este trabalho visou mensurar os níveis de expressão gênica e de síntese proteica das globinas a e y em células em que o gene PIP4KIla foi silenciado. Os resultados obtidos revelaram que a expressão gênica da globina a apresentou tendência de elevação mediante o silenciamento do gene PIP4KIla, ocorrendo o oposto em relação à globina $\gamma$. As análises a nível protéico não confirmaram as de expressão gênica, o que evidencia a necessidade de repetição dos experimentos. No entanto, ainda assim os dados obtidos corroboram a hipótese de relação entre a expressão do gene PIP4KIl $\alpha$ e a dos genes das globinas $\alpha$ e $y$, abrindo horizontes para a descoberta de novas medidas terapêuticas para hemoglobinopatias.
\end{abstract}

Palavras-chave: Silenciamento, Globinas, PIP4KIla

\section{Introdução}

A enzima fosfatidilinositol-5-fosfato-4-quinase, subtipo alfa (PIP4KIla), responsável pela produção do segundo mensageiro fosfatidilinositol 4,5 fosfato, o qual exerce papel regulatório em vários processos celulares, inclusive na expressão gênica, é amplamente expressa em células hematopoiéticas durante as etapas da diferenciação eritróide. Estudos prévios sugerem que a expressão do gene PIP4KIIA pode estar relacionada à expressão dos genes de globinas. O presente trabalho teve por objetivo silenciar o gene PIP4KIla em células eritroleucêmicas imortalizadas (HEL) para observação do efeito da depleção da enzima PIP4KIla na síntese das cadeias globínicas $\alpha$ e $\gamma$.

\section{Resultados e Discussão}

Após a transdução de células HEL com partículas lentivirais contendo RNA de interferência (RNAi) para o gene PIP4KIla e posteriores análises por Quantitative Real Time PCR e Western Blotting, observou-se que o nível de expressão gênica de globinas $\alpha$ apresentou discreta tendência de diminuição, ao contrário da produção protéica, que aumentou mediante 0 silenciamento do gene PIP4KIla. A globina $\mathrm{y}$ sofreu redução de síntese, em comparação às células controle, tanto a níveis de expressão gênica, quanto de produção protéica.

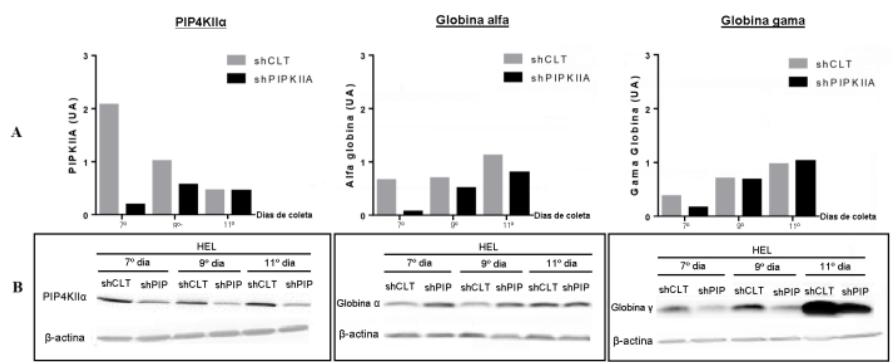

Figura 1. A. Gráficos representativos de $\mathrm{qPCR}$ da expressão dos genes PIP4KIla e das globinas $\alpha$ e $y$ após transdução de células eritroleucêmicas imortalizadas. B. Western Blotting da enzima PIP4KIla e das globinas a e Y após o silenciamento do gene PIP4KIla em células eritroleucêmicas imortalizadas.

\section{Conclusões}

Tais resultados, apesar de preliminares, corroboram a hipótese de relação entre a expressão do gene PIP4KIla e aquela dos genes das globinas a e $\gamma$. No entanto, os experimentos deverão ser repetidos com outras linhagens celulares imortalizadas, bem como em precursores eritróides CD34+, a fim de melhor investigar a possível influência da PIP4KIla sobre a expressão dos genes de globinas.

\section{Agradecimentos}

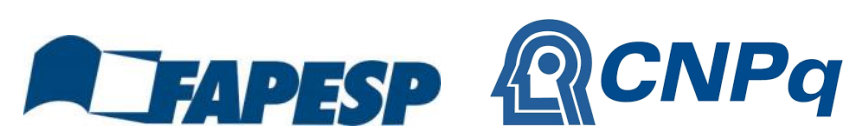

